\title{
The Future of Employment Revisited: How Model Selection Determines Automation Forecasts
}

\author{
Fabian Stephany $\mathbb{W}^{1}$ and Hanno Lorenz ${ }^{2}$ \\ ${ }^{1}$ Oxford Internet Institute,, fabian.stephany@oii.ox.ac.uk, , ORCID ID 0000-0002-0713-6010 \\ ${ }^{2}$ Agenda Austria, Türkenstraße 25, 1090 Vienna,, ORCID ID 0000-0003-4577-4117
}

April 29, 2021

\begin{abstract}
The uniqueness of human labour is at question in times of smart technologies. The 250 years-old discussion on technological unemployment reawakens. Prominently, Frey and Osborne (2017) estimated that half of US employment will be automated by algorithms within the next 20 years. Other follow-up studies conclude that only a small fraction of workers will be replaced by digital technologies. The main contribution of our work is to show that the diversity of previous findings regarding the degree of job automation is, to a large extent, driven by model selection and not by controlling for personal characteristics or tasks. For our case study, we consult experts in machine learning and industry professionals on the susceptibility to digital technologies in the Austrian labour market. Our results indicate that, while clerical computer-based routine jobs are likely to change in the next decade, professional activities, such as the processing of complex information, are less prone to digital change ${ }^{1}$
\end{abstract}

JEL classification: E 24, J 24, J 31, J 62, O 33.

Keywords: Classification, Employment, GLM, Technological Change.

\footnotetext{
${ }^{1}$ The authors would like to thank Monika Köppel-Turyna, Harald Oberhofer and Wolfgang Nagl for their support and helpful comments.
} 


\section{Introduction}

The motivation behind our work is the discussion about technological unemployment, which has accompanied technological processes throughout the last 250 years. The debate about the susceptibility of human labour to digital technologies accelerated since a prominent study by Frey and Osborne (2017) concluded that half of US employment will be automated within the next 20 years, which would pose a sizeable thread to societal stability ${ }^{2}$. Their estimations are the basis for several follow-up studies, which infer that the share of jobs at risk is much smaller. Our work examines the reason for the stark diversity in previous findings about job automation. We propose that differences in the degree of susceptibility emerge mainly from model selection. In order to test this assumption, we conduct a case study similar to Frey and Osborne with a survey among Austrian research and industry experts. Our model testing confirms that differences in previous findings on the automation of jobs are mainly driven by the design of the model, rather than heterogeneity among tasks within occupations. Our results indicate that, while clerical computer-based routine jobs are likely to change in the next decade, professional activities, such as the processing of complex information, are less prone to digital change.

Machines have both complemented and competed with human labour in the past. Inventive ideas and creative destruction, as Schumpeter (1942) puts it, have competed with powerful social and economic interest over the technological status quo. Various movements, such as the Luddites, who destroyed new machinery in the $18^{\text {th }}$ century textile industry, have tried to deter progress in times of rising unemployment. However, the Luddite fallacy has found its way into the literature, as employment has not been eradicated alongside fast technological development, but instead continued to expanded. Rather than eliminating human labour as such, technological advancements have changed a number of work profiles and led to the creation of new professions.

Whenever modern society experiences technological advancement, concerns about technologically induced unemployment arise. In recent history, technological progress has often been linked to a displacement in specific professions (Bresnahan, 1999) or even entire industries (Charles et al. 2013 Jaimovich and Siu, 2012). However, to date, technological progress has not caused mass

\footnotetext{
${ }^{2}$ In addition and interaction with other global dynamics, such as rising income inequalities Stephany, 2017. 2019) or climate change and mass migration (Hoffmann et al. 2019).
} 
unemployment. We have seen a shift in labour from the agricultural sector to manufacturing branches, and further into the service sector (Autor, 2015). Overall employment has been steadily increasing worldwide, despite (or perhaps because of) technological progress. Hence, new technologies display two opposite effects on employment (Aghion and Howitt, 1994). On the one hand, technologies substitute human labour in order to decrease production costs and increase productivity. This displacement effect lowers employment. On the other hand, reduced production costs increase real income and hence demand. The latter effect fosters production and demand for labour.

According to Goldin and Katz (1998), technological progress led to the simplification of work processes in the 19th century. A combination of machines and unskilled labour substituted skilled labour and decreased demand in terms of skills. However, as technologies improved, technological job displacement shifted away from skilled to unskilled labour. Acemoğlu and Restrepo (2017) calculate that an increased use of robots in the US economy between 1990 and 2007 had a negative effect on the labour market. According to their calculations, an increase in the number of industrial robots by one, per 1,000 people employed, reduces the employment-to-population ratio by 0.18 to 0.34 percentage points.

Similar to signs of competition with rooters for physical work, McAfee and Brynjolfsson (2014) emphasize that computerization has now started challenging human performance in cognitive tasks. Beaudry et al. (2016), in an empirical analysis, find evidence that the demand for skilled labour has been declining in recent years. This is an indication that skills under pressure of substitution are altering as technological progress persists. Autor and Dorn (2013) show that the implementation of computer-based technologies has put pressure on wages. As routine tasks are increasingly automated, displaced workers reallocate to the lower skilled service sector with deteriorating wages. According to Goos et al. (2009), this has resulted in the increased polarization of the labour market in a number of developed economies (see also Dustmann et al., 2009). Increasing demand for well-paid jobs in which non-routine cognitive tasks are performed, as well as non-routine manual work at the lower end of the income distribution, in combination with the automation of repetitive cognitive skills, is forcing employment away from the middle of the income distribution (see also Autor et al., 2003, Autor, 2013, Michaels et al., 2014). 
Recent publications, such as Ford (2015), raise concerns that "this time it could be different" and there will be no room for creating new jobs. Frey and Osborne (2017) set the starting point for a series of papers that attempts to calculate the impact of digital technologies on the demand for human labour. Based on their original data, collected during a workshop involving machine learning experts, several papers about the susceptibility of jobs have been published.

Yet, transferring the data on susceptibility from the US labour market to European economies is challenging in many respects. Until now, there has been no piece of research that has analysed the impact of computer automation on the labour market by using newly collected data from European countries. This approach allows us to correct the shortcomings in transferring the original US data $\left(\mathrm{O}^{*} \mathrm{NET}\right)$ of Frey and Osborne (2017) to the International Standard Classification of Occupations (ISCO). It also adjusts for regional particularities in labour markets, for example, differences in regulation or cultural particularities. Even though technological innovations have become market-ready, customers may hesitate to substitute them for human interaction. In addition, we analyse the possibility of a non-linear relationship between education and future digitalization, since both low- and high-skilled jobs are assumed to be less affected by digital technologies than medium-skilled professions Dustmann et al. (2009).

Addressing previous limitations, we assume that the strong differences in the degree of susceptibility between Frey and Osborne (2017) and follow-up studies is due to model selection. As case study, our investigation examines the degree of future digitalization of job profiles in Austria. We link expert opinions with individual data from the OECD's PIAAC data, which in turn allow for heterogeneity among workers within the same occupation. Our results indicate that, models with a binary outcome, as applied by Frey and Osborne (2017) result in a much higher share of jobs at risk than models with a fractional dependent variable, as used by the OECD. In both settings, clerical computer-based routine jobs are likely to change in the next decade, professional activities with the processing of complex information are less prone to digital change. The following section 2 describes the methodology and data, followed by the 3 section, which summarizes the results, while the last section concludes the paper. 


\section{Data and Methods}

Frey and Osborne (2017) were the first to attempt to quantify the potential of computer-based job displacement in the near future. Based on the estimates of robotic experts, the authors calculated the susceptibility to computerization of different jobs, according to the $\mathrm{O}^{*} \mathrm{NET}$ database in the US. They conclude that $47 \%$ of the jobs in the US are at a high risk ( $>70 \%$ probability) of being replaced due to computerization. Bowles (2014) applies the same method and transfers the results to European economies using the differences in the sectoral structure of each country. He concludes that $54 \%$ of jobs in Austria have a high risk of being displaced by computers.

Arntz et al. (2016) emphasize that the method used by Frey and Osborne (2017) overstates the share of jobs susceptible to computerization. As Frey and Osborne (2017) do allow for heterogeneity in tasks between different jobs, they do not allow for alterations in the tasks within one occupation. According to Arntz et al. (2016), one profession may contain different sets of tasks, and thus the risk of computerization could vary within this profession. Using PIAAC survey data, they combine information about the composition of tasks within each job profile with information from robotic experts on the susceptibility of jobs for the US labour market. They further transfer the results to other OECD member countries, indicating that $9 \%$ of US workers and $12 \%$ of Austrian workers are at high risk due to computerization ${ }^{3}$ Among OECD countries, Austria, as well as Germany, displays the highest share of the workforce at a high risk of computerization.

For the German labour market, Dengler and Matthes (2015) relate the risk of job automation to the tasks that are characteristic of each profession. They compute the share of tasks that can be classified as routine based, according to the classification by Spitz-Oener (2006). According to their findings, $15 \%$ of German workers are employed in jobs with a high risk of automation. Likewise, for Austria, Peneder et al. (2016) find that 12\% of Austrian workers primarily perform routine-based tasks.

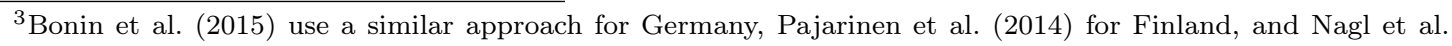
(2017) for the Austrian economy. According to Nagl et al. (2017), 9\% of Austrian workers have a high risk of being automated. 
Similar to the approach by Frey and Osborne (2017), we begin our analysis with expert opinions. Between $7^{\text {th }}$ December 2017 and $7^{\text {th }}$ January 2018, we consulted Austrian industry experts and machine learning professionals. The final data set contained 35 individual experts' opinions, with 14 individuals representatives of Austrian companies in the fields of construction, consulting, insurance, investment, media, real estate and retail, and 21 responses were from industry and academic experts in machine learning and AI. Experts from both groups were individually requested to participate in an online survey. In comparison, the expert workshop by Frey and Osborne (2017), which was held in 2013 at Oxford University's Engineering Sciences Department, included 70 machine learning experts (Brandes and Wattenhofer, 2016). Together with their team of experts, Frey and Osborne (2017) initially labelled 70 out of 703 US jobs. These binary labels were then used to predict risks of automation for all US professions. The resulting estimations formed the basis of the aforementioned studies in a European context. However, for the estimation of impacts of digital technologies on the Austria labour market, our expert opinions are better suited than the opinions stemming from the Oxford seminar. Machine learning experts are familiar with the scientific principles of the technologies disrupting the labour market, but they may not be fully aware of the social environments in which smart technologies could be implemented. For example, even when chatbots in the financial service sector become market-ready, from a technological point of view, some customers will still prefer interaction with a human. In addition, the gap between technological readiness and implementation varies to a sizeable extent between countries and cultural backgrounds. In order to address this aspect of the application of new technologies, we consulted Austrian experts from the field of machine learning/AI and professionals from various industry domains.

The participants in our survey were asked about their opinion on the 100 most common professions in Austria, as listed in Table 1 In contrast to the focus on the susceptibility to computerization (Frey and Osborne, 2017), we asked our experts: "Do you think that the tasks, which are characteristic of this profession today, will be substituted, to a significant degree within the next 10 years, by algorithmic technologies (such as machine learning, computer vision and natural language processing) or mobile robotics?" (Yes=1/No=0). This question analyses the degree to which the 
nature of certain professions is going to change due to technological advancement. Answers to this question do not necessarily reflect the risk of occupations being fully substituted by technologies.

Experts were allowed to avoid answering the question in relation to as many jobs as they wished. However, in the end, only a small minority of jobs remained unlabelled. In order to extract an indicator of future digitalization that is unique to each profession, we calculated three measures: the mean and mode of all expert opinions, as well as an indicator of the experts' consensus on each profession. The consensus is equivalent to the mode, but only for those professions to which at least $75 \%$ of all experts attributed the same label. With this definition of consensus, 45 professions remained and received a binary label, as shown in Table 1.

\section{TABLE[1 ABOUT HERE}

In the second step, the profession labels were matched with profession groups from the Austrian and German samples of the 2015 OECD survey of the PIAAC. The PIAAC survey supplied our analysis with individual characteristics, as well as job- and firm-level indicators. In addition, the survey contains information about the frequency of specific tasks performed by interviewed individuals during their average working routine. These tasks, as listed in Table 2 include human interaction, IT usage, physical work, problem-solving, reading or understanding, and writing or calculating. As the individuals provided answers about the frequency by which they undertake a given task, we normalized the answers according to the value of the working hours as follows: 'on a daily basis' (value=1), 'less than daily, but more than once a week' (value=1/2), 'less than once a week, but more than once a month' (value=1/7), 'less than once a month' (value=1/30), or 'never' (value $=0)$. This labelling is likewise applied by Arntz et al. $(2016)$, since it reflects the differences in scale between days, weeks and months.

\section{TABLES 2 ABOUT HERE}

Thirdly, the expert opinions about the future change of professions are related with the PIAAC data. These opinions about professions are matched via the ISCO-08 classification for each individual's jol 4 . The PIAAC survey is conducted in a way that it contains a representative sample of the population. However, not all observations within the survey contain answers to all questions.

\footnotetext{
${ }^{4}$ Only the German PIAAC sample contains the respective ISCO-08 Level 4 job classifications. Hence, the fitting of the inferential models is performed only with the labelled subset of the German employees.
} 
Thus, the specification of the model leads to a loss in observations due to non-responses. There is no reason to assume that the loss in observation systematically changes the sample. We perform a mean imputation for the non-response values, which increases the model's sample size by $55 \%$, but does not lead to a significant difference in results. Compared to the 2012 labour force survey, our sample displays a slight shift towards younger age groups. Furthermore, the sample shows a higher share of female employees (for details, see Table 3). Nevertheless, the impact of technological change on job profiles stays unchanged.

In order to relate the above-mentioned characteristics to the given expert opinions about the individual's job, we test three inferential models. The consensus indicator serves as the dependent variable, while various combinations of personal-, job- and firm-level controls, as well as task frequencies, are included in the model (Table 33. The correlation analysis in Table 6 across all characteristics only indicates a sizeable association between the three test score variables. All measures are considered at the individual level with a sample of 507. The extrapolated sample contains 4,438 individuals: 2,051 from Austria and 2,387 from Germany. In a first round, we apply a logit model. This stepwise procedure is illustrated in Columns (1)-(6) in Table 4 . The Akaike information criterion indicates that Model (6), with all controls, yields the best model fit. In the second round of the model selection, we test a linear discriminant analysis (LDA) with a Bayesian estimation of the dependent variable (James et al. 2013 , Chapter 4$)^{5}$, which is similar to the approach chosen by Frey and Osborne (2017). In order to compare the logit and LDA models, we apply a cross-validation method ( $40 \%$ training sample). The comparison of the in-sample predictions shows that the logit model (area under the curve (AUC) 6.94 ) slightly outperforms the LDA model (AUC: 0.92). The estimations of the LDA model are very similar to the results of the logit model, as summarized in Table 5 Lastly, we compare the results of the logit model with a fractional response model (Papke and Wooldridge, 1993) 7 In this model, the mean of the experts' opinions is considered as the dependent variable. Accordingly, the fractional model refers

\footnotetext{
${ }^{5}$ The probability of belonging to class $\mathrm{k}$, given characteristics $\mathrm{X}$, is described by $P(Y=k \mid X=x)=\frac{f_{k}(x) \pi_{k}}{P(X=x)}$, , while $f_{k}(x)$ describes the probability of $X=x$, given that $Y=k$, while $\pi_{k}$ is the prior probability of observing $Y=k$.

${ }^{6}$ The AUC measures the area under the receiver operating characteristics (ROC) curve. The AUC is a measure of prediction accuracy, since the ROC curve plots the true positive rate against the false positive rate of a prediction model.

${ }^{7} E(y \mid X)=\frac{e^{\left(\beta^{\prime} X\right)}}{1+e^{\left(\beta^{\prime} X\right)}}$, while $\beta^{\prime} X=\beta_{0}+\beta_{1} x_{1}+\cdots+\beta_{k} x_{k}$
} 
to a larger sample size. However, the results in Table 4 Columns (6) and (7), show that the logit model still yields a significantly better model fit.

\section{TABLE 3 AND 4 ABOUT HERE}

After identifying the appropriate model environment, the logit model (1) is used to predict the digitalization probabilities, $\mathrm{P}(\mathrm{y}=1 \mid \mathrm{X})$, for all individuals in the sample, based on their set of characteristics $\left(\beta^{\prime} X\right)$. Here, individuals with professions, which have not been judged by our experts, also obtain a probability. The average estimated probabilities of future digitalization are shown in Figure2, and are aggregated for ISCO-08-Level 1 (Figure 3) and ISCO-08 Level 2 (Figure 4) professions in Austria.

$$
P(y=1 \mid X)=\frac{1}{1+e^{-\left(\beta^{\prime} X\right)}}, \quad \beta^{\prime} X=\beta_{0}+\beta_{1} x_{1}+\cdots+\beta_{k} x_{k}
$$

Based on the consensus of our experts, we are able to specify a degree of future digitalization for 47 occupations. More than $75 \%$ of our experts agreed that the characteristic tasks of these professions will change to a significant degree with the development of digital technologies and mobile robotics. With the use of the PIAAC data set, we are able to relate the degree of digitalization to personal characteristics and occupation-specific tasks. Based on this relationship, we estimate

the degree of digitalization for all professions in the data set. In contrast to the work by Frey and Osborne (2017), we apply local experts' opinions and perform our estimations on the basis of individual characteristics.

\section{Results}

For some tasks we see a clear relationship with the consensus of our experts. In Figure 1 , the frequencies of the 39 tasks are compared to the consensus of our experts. On average, some tasks, such as coding (itusage_code), are, on average, performed less than once a month, while others, such as sharing information with others (human_share), are carried out on an almost daily basis. For some activities, prevalence does not differ significantly between the two consensus job groups, for example, itusage_code or human_share. However, for most of the activities, a clear separation between the consensus groups is visible. Activity involving long physical work (physical_long) is 
less commonly performed in professions that are expected to change during digitalization, according to our experts. Other activities show the exact opposite pattern. Calculating (wricalc_calculator) or the use of computer software Excel (itusage_excel), for example, is much more prevalent in professions that are expected to change. This observation, confirmed by the findings of the inferential model, is a first indication that professions with a high degree of computer-based office routines are more likely to change in light of digital technologies.

\section{FIGURE 1 ABOUT HERE}

In addition to the 39 tasks, individual-, job- and firm-specific characteristics can help explain the consensus opinions of our experts, as shown in Table 4 . The final and full model (6) indicates that, apart from work activities, education, firm sector, job responsibility and training are related to the degree of future digitalization. Individuals with a high level of education, who work in a job that requires training or responsibility, are typically less likely to be employed in an occupation that is going to change significantly. Interestingly, our results indicate a non-linear relationship with education. Individuals with a medium level of schooling are employed in jobs with a higher level of future digitalization than workers with high or low levels of education.

Our model indicates that certain work activities are strongly related to the degree of digital change in the workplace. Tasks such as extracting complex information by reading books (reading_book) or writing non-routine content (wricalc_report) are related to professions with a low degree of technological change. On the other hand, activities such as calculations (wricalc_calculator) or extracting simple information (wricalc_news) are associated with a stronger change in the job profile in the near future. McAfee and Brynjolfsson (2014), for example, show that news stations have begun implementing algorithms that are able to write simple pieces in the context of sports or weather forecasts. Moreover, for professions that predominantly rely on physical labour, impacts of technological change are also low.

\section{FIGURE 2 ABOUT HERE}

Among occupations, there is a clear trend (Figures 3 and 4p: clerical support workers, who perform simple computer-based office routines, are highly susceptible to technological changes. This is in line with previous findings. On the other hand, professionals, who work with complex 
and unstructured information, and skilled workers in agricultural fields, who perform physical work, are less likely to experience major changes in their job profile. Professional occupations involving teaching and healthcare within legal, social or cultural environments (Figure 4) exhibit particularly low probabilities of digital transformation. This finding is consistent for individuals working in a job that requires an academic degree, as well as for those without such a qualification. On average, most occupations show a probability of change between $40 \%$ and $60 \%$.

\section{FIGURES 3 and 4 ABOUT HERE}

When comparing our model findings, clear differences emerge with regard to the degree of susceptibility in employment to digital technologies. However, our model testing suggests that these difference are mainly driven by model selection, rather than heterogeneity among tasks within occupations. Table 5 compares the set-ups of our research and previous studies.

\section{TABLE 5 ABOUT HERE}

Two types of model settings are prevalent. Frey and Osborne (2017) start with binary opinions of experts and extrapolate them via a classification model for all occupations. Bowles (2014) directly transfers these estimations to European labour markets. Both studies conclude that a high share of workers ( $47 \%$ in the US and $54 \%$ in Austria) share a high risk of computerization. Arntz et al. (2016) and Nagl et al. (2017), on the other hand, begin with discrete probabilities and apply a fractional model in order to extrapolate. In comparison, they show that only about $12 \%$ and $9 \%$, respectively, have an automation risk of more than $70 \%$. In light of these contradictory findings, our model testing suggests that the different estimations are mainly due to the choice of model. Binary models yield a bimodal distribution of predicted probabilities with large high-risk groups. Fractional models lead to a bell-shaped distribution of probabilities with relatively low levels of high-risk individuals. Our own estimations for a fractional model (Figure 5 confirm this assumption. The ranking of occupational classes does not change significantly after the fractional model (Figure 6) has been used. However, predicted probabilities converge towards the mean.

\section{FIGURES 5 AND 6 ABOUT HERE}

When comparing the outcome of the binary and fractional model, the results of the latter contain a lower number of covariates, which are statistically relevant to the degree of digitalization. 
The fractional model, however, does not show any statistical significance concerning the covariates that have not been relevant in the binary model. In the fractional model, education and job responsibility show no statistical significance. Likewise, the tasks of speaking in front of humans, reading books, using words, and coding are not significant in the case of the fractional model environment. This general observation is not surprising from a statistical point of view, since the formally strict binary outcome in a small sample has now been changed to a smooth continuous scale in a sample twice the original size. However, it becomes clear that some covariates, such as physical work, writing reports, performing calculations or firm characteristics, are still aligned with the distribution of the fractional model. The distribution of other covariates has been polarized by the truncation of the binary model. The unconditional distributions of the binary and fractional models are shown in Figures 7 and 8

\section{FIGURES 7 AND 8 ABOUT HERE}

Similarly, when moving the threshold of consensus from our final value towards 0.5 , the outcome of the binary model starts to slightly approach the results of the fractional model. However, no significant changes appear, except for a deterioration in statistical significance.

\section{Conclusion}

Our model explicitly diverges from the approach taken in previous contributions to this field. We assume that the diversity of previous estimations of job susceptibility stems from model specification. In order to test this assumption we conducted a case study with local expert opinions about near-term changes in occupations in Austria. This is a significant conceptual improvement in contrast to prior investigations (Arntz et al., 2016, Bowles, 2014), which studies rely on the judgement of machine learning experts concerning the US labour market, stemming from the workshop organized by Frey and Osborne (2017). However, the authors do not allow for heterogeneity within the same profession. This limitation is ruled out by our model approach. Past findings are, in part, contradictory. $47 \%$ of jobs in the US (54\% in Austria) share a high risk of automation, according to Frey and Osborne (2017) and Bowles (2014), while Arntz et al. (2016) and Nagl et al. (2017) estimate this share to be $12 \%$ and $9 \%$, respectively, for Austria. Our findings show that these 
differences are mainly driven by the selection of the model, and not so much by controlling for personal characteristics or tasks.

Our findings show that the tasks that humans perform during their typical working day are of significant importance when determining the impact of digital technologies on the future workspace. Activities such as extracting complex information by reading books or writing non-routine content reduce the impact of technologies. On the other hand, tasks such as calculations or extracting simple information will lead to a stronger change in job profiles in the next decade. Furthermore, as the current generation of technological progress has a stronger impact on cognitive and routine tasks than on physical labour, the extent of physical work within a job profile reduces the effect of digital change. Although the future of work will most likely be a complementary partnership between humans and computers, workers performing computer-related routine activities, such as spreadsheet calculations or Internet usage (Stephany, 2021b a; Stephany et al., 2020), are under stronger pressure to adapt. Our findings about the "inverse U-shaped" relationship between education and digitalization support previous hypotheses about the skill-based polarization of the labour market (Goos et al., 2009). This suggests further polarization in the near future.

Our results indicate that some jobs can expect to change more than others during the current phase of digital progress. This is surely not the first time in history that this has happened. During the Industrial Revolution, technological advancements made manufacturing jobs less intensive in terms of monotonous physical labour. In contrast to the age of the steam engine, today's technologies, such as algorithms, unfold their potential in disciplines that require routine cognitive effort. Typical computer-backed office tasks, such as in the clerical professions, are more exposed to digital transformation than occupations marked by physical labour. Likewise, jobs in which complex information is processed and that require a high level of education and training are less prone to digital change in the near future. Teaching and health-care professionals working within in legal, social or cultural environments belong to occupations with the lowest level of technological pressure. In the near future, these disciplines can be regarded as a sustainable choice for future generations seeking job security in unsteady times. 
In addition, while most research focuses on human labour that can be replaced by technology, little attention has been given to the effect that digital technologies have on job creation. As our findings improve the understanding of the displacement effect of technologies, more research should be conducted in order to incorporate the effect of job creation, and in turn appreciate the full impact of the technological change on the labour market. 


\section{References}

Acemoğlu, D., Restrepo, P., 2017. Robots and jobs: Evidence from us labor markets.

Aghion, P., Howitt, P., 1994. Growth and unemployment. The Review of Economic Studies 61 (3), 477-494.

Arntz, M., Gregory, T., Zierahn, U., 2016. The risk of automation for jobs in oecd countries: A comparative analysis. OECD Social, Employment, and Migration Working Papers (189).

Autor, D., 2013. The" task approach" to labor markets: an overview. Tech. rep., National Bureau of Economic Research.

Autor, D., 2015. Why are there still so many jobs? the history and future of workplace automation. Journal of Economic Perspectives 29 (3), 3-30.

Autor, D., Dorn, D., 2013. The growth of low-skill service jobs and the polarization of the us labor market. American Economic Review 103 (5), 1553-97.

Autor, D., Levy, F., Murnane, R. J., 2003. The skill content of recent technological change: An empirical exploration. The Quarterly Journal of Economics 118 (4), 1279-1333.

Beaudry, P., Green, D. A., Sand, B. M., 2016. The great reversal in the demand for skill and cognitive tasks. Journal of Labor Economics 34 (S1), S199-S247.

Bonin, H., Gregory, T., Zierahn, U., 2015. Übertragung der studie von frey/osborne (2013) auf deutschland. Tech. rep., ZEW Kurzexpertise.

Bowles, J., 2014. The computerisation of european jobs-who will win and who will lose from the impact of new technology onto old areas of employment. Bruegel Blog 17.

Brandes, P., Wattenhofer, R., 2016. Opening the frey/osborne black box: Which tasks of a job are susceptible to computerization? arXiv preprint arXiv:1604.08823.

Bresnahan, T. F., 1999. Computerisation and wage dispersion: an analytical reinterpretation. The Economic Journal 109 (456), 390-415.

Charles, K. K., Hurst, E., Notowidigdo, M., 2013. Manufacturing decline, housing booms, and non-employment.

Dengler, K., Matthes, B., 2015. Folgen der digitalisierung für die arbeitswelt: Substituierbarkeitspotenziale von berufen in deutschland. Tech. rep., IAB-Forschungsbericht.

Dustmann, C., Ludsteck, J., Schönberg, U., 2009. Revisiting the german wage structure. The Quarterly Journal of Economics $124(2), 843-881$.

Ford, M., 2015. Rise of the Robots: Technology and the Threat of a Jobless Future. Basic Books.

Frey, C. B., Osborne, M., 2017. The future of employment. How susceptible are jobs to computerisation. 
Goldin, C., Katz, L. F., 1998. The origins of technology-skill complementarity. The Quarterly Journal of Economics $113(3), 693-732$.

Goos, M., Manning, A., Salomons, A., 2009. Job polarization in europe. American economic review 99 (2), $58-63$.

Hoffmann, R., Dimitrova, A., Muttarak, R., Crespo Cuaresma, J., Stephany, F., Peisker, J., 2019. Quantifying the evidence on environmental migration: A meta-analysis on country-level studies. In: Population Association of America Annual Meeting, Austin, USA.

Jaimovich, N., Siu, H. E., 2012. The trend is the cycle: Job polarization and jobless recoveries. Tech. rep., National Bureau of Economic Research.

James, G., Witten, D., Hastie, T., Tibshirani, R., 2013. An introduction to statistical learning. Vol. 112. Springer.

McAfee, A., Brynjolfsson, E., 2014. The second machine age. WW Norton.

Michaels, G., Natraj, A., Van Reenen, J., 2014. Has ict polarized skill demand? evidence from eleven countries over twenty-five years. Review of Economics and Statistics 96 (1), 60-77.

Nagl, W., Titelbach, G., Valkova, K., 2017. Digitalisierung der arbeit: Substituierbarkeit von berufen im zuge der automatisierung durch industrie 4.0; endbericht.

Pajarinen, M., Rouvinen, P., et al., 2014. Computerization threatens one third of finnish employment. ETLA Brief $22(13.1), 2014$.

Papke, L. E., Wooldridge, J., 1993. Econometric methods for fractional response variables with an application to 401 (k) plan participation rates.

Peneder, M., Bock-Schappelwein, J., Firgo, M., Fritz, O., Streicher, G., 2016. Österreich im Wandel der Digitalisierung. WIFO, Österreichisches Institut für Wirtschaftsforschung.

Schumpeter, J., 1942. Creative destruction. Capitalism, socialism and democracy 825.

Spitz-Oener, A., 2006. Technical change, job tasks, and rising educational demands: Looking outside the wage structure. Journal of labor economics 24 (2), 235-270.

Stephany, F., 2017. Who are your joneses? socio-specific income inequality and trust. Social indicators research $134(3), 877-898$.

Stephany, F., 2019. It deepens like a coastal shelf: Educational mobility and social capital in germany. Social Indicators Research $142(2), 855-885$.

Stephany, F., 2021a. One size does not fit all: Constructing complementary digital reskilling strategies using online labour market data. Big Data \& Society 8 (1), 20539517211003120.

Stephany, F., 2021b. When does it pay off to learn a new skill? revealing the complementary benefit of cross-skilling. Stephany, F., Braesemann, F., Graham, M., 2020. Coding together-coding alone: the role of trust in collaborative programming. Information, Communication \& Society, 1-18. 


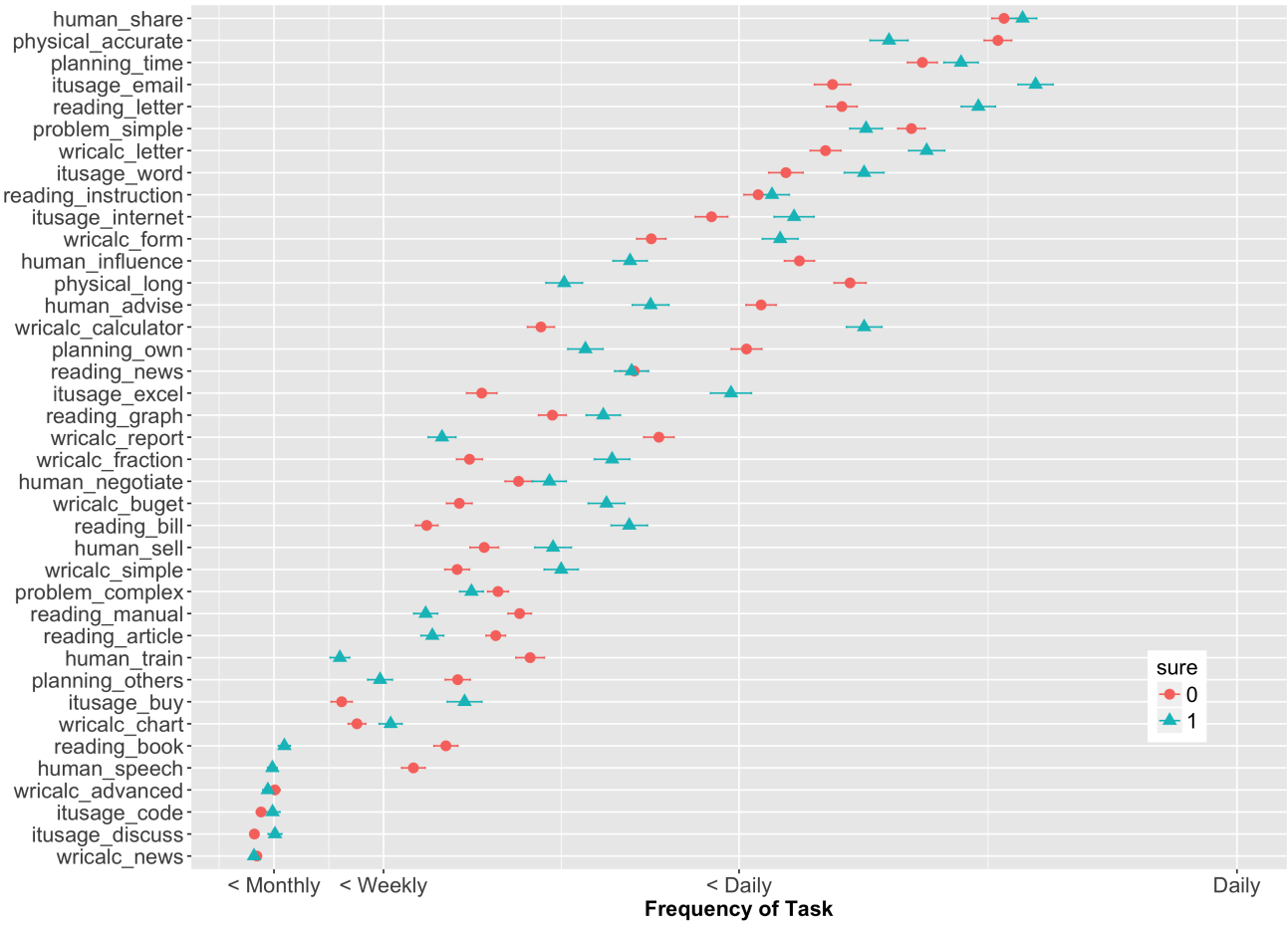

Figure 1: Tasks at work: Of the 39 tasks, some are performed on a daily basis, while others are carried out only once a month. Some of the activities vary significantly between jobs with a high and low degree of future digitalization. 


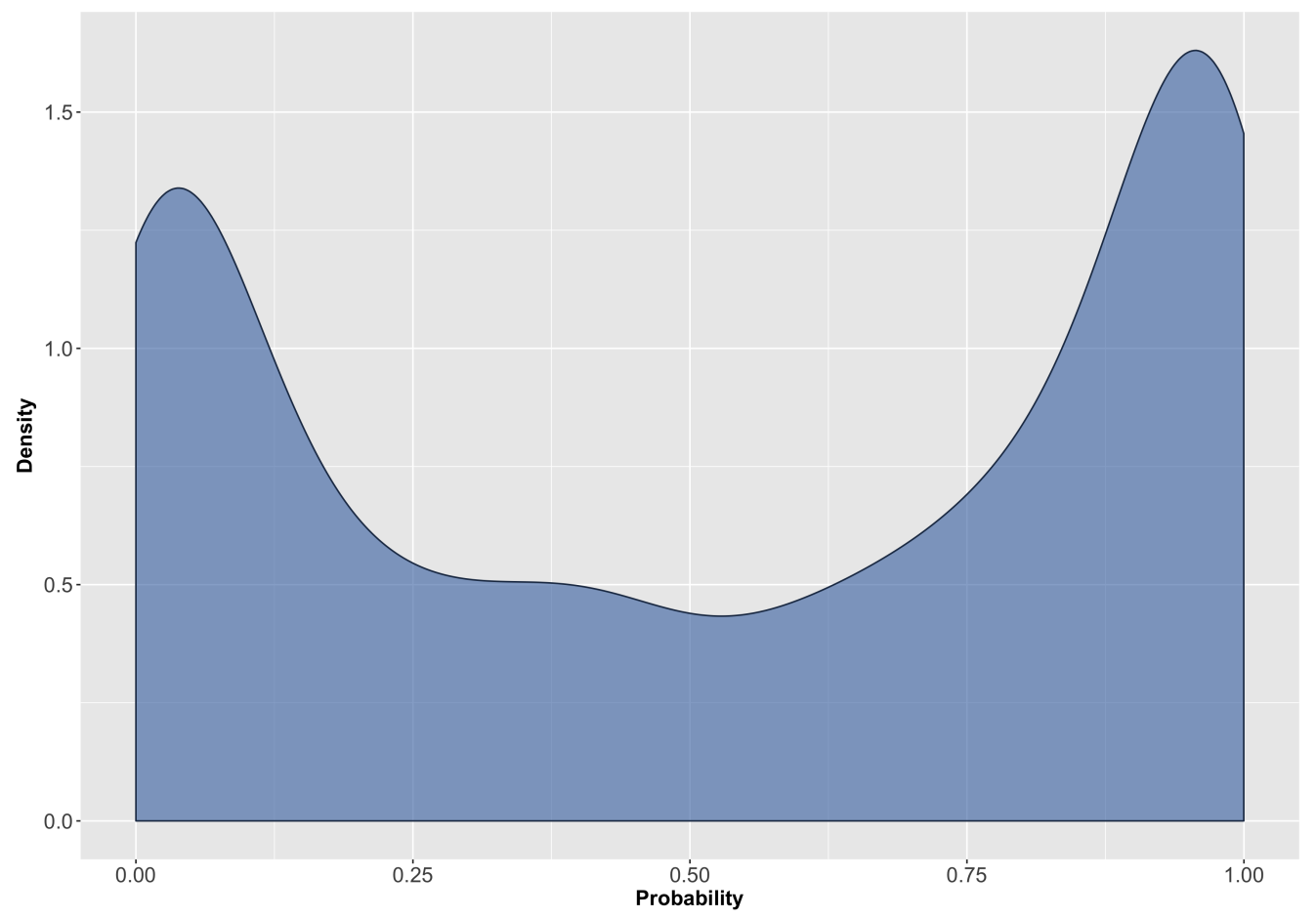

Figure 2: Future digitalization: Jobs in Austria are polarized between high and low levels of future digitalization. The distribution of individual levels of future digitalization mirrors the initial estimation of our experts. 


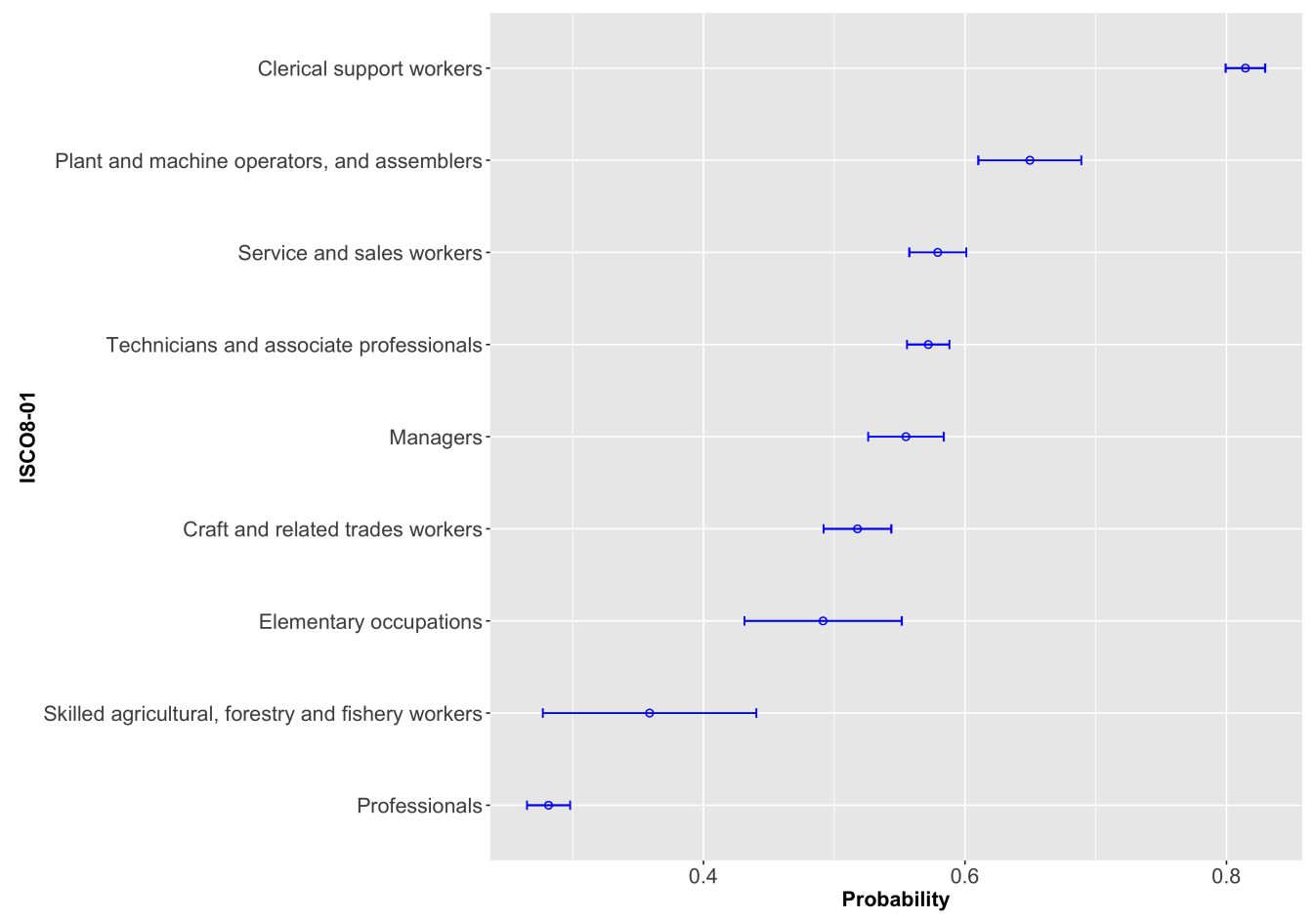

Figure 3: ISCO Level 1: For the top level of occupations, clerical professions have, by far, the highest risk of future digitalization. Professionals are at the lower end of the scale. 


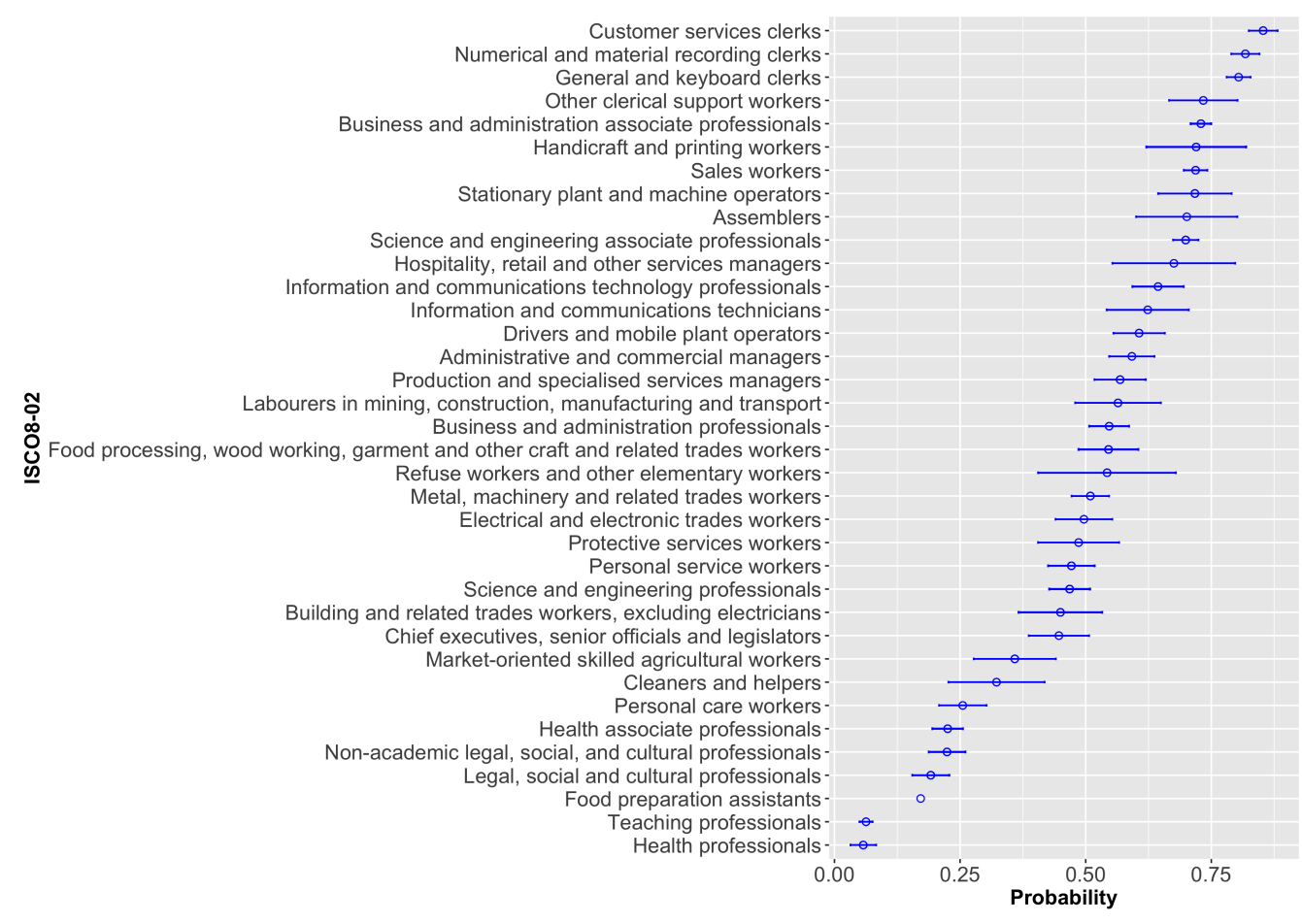

Figure 4: ISCO Level 2: Professional occupations involving teaching and healthcare, within legal, social or cultural environments, exhibit particularly low probabilities of digital transformation. 


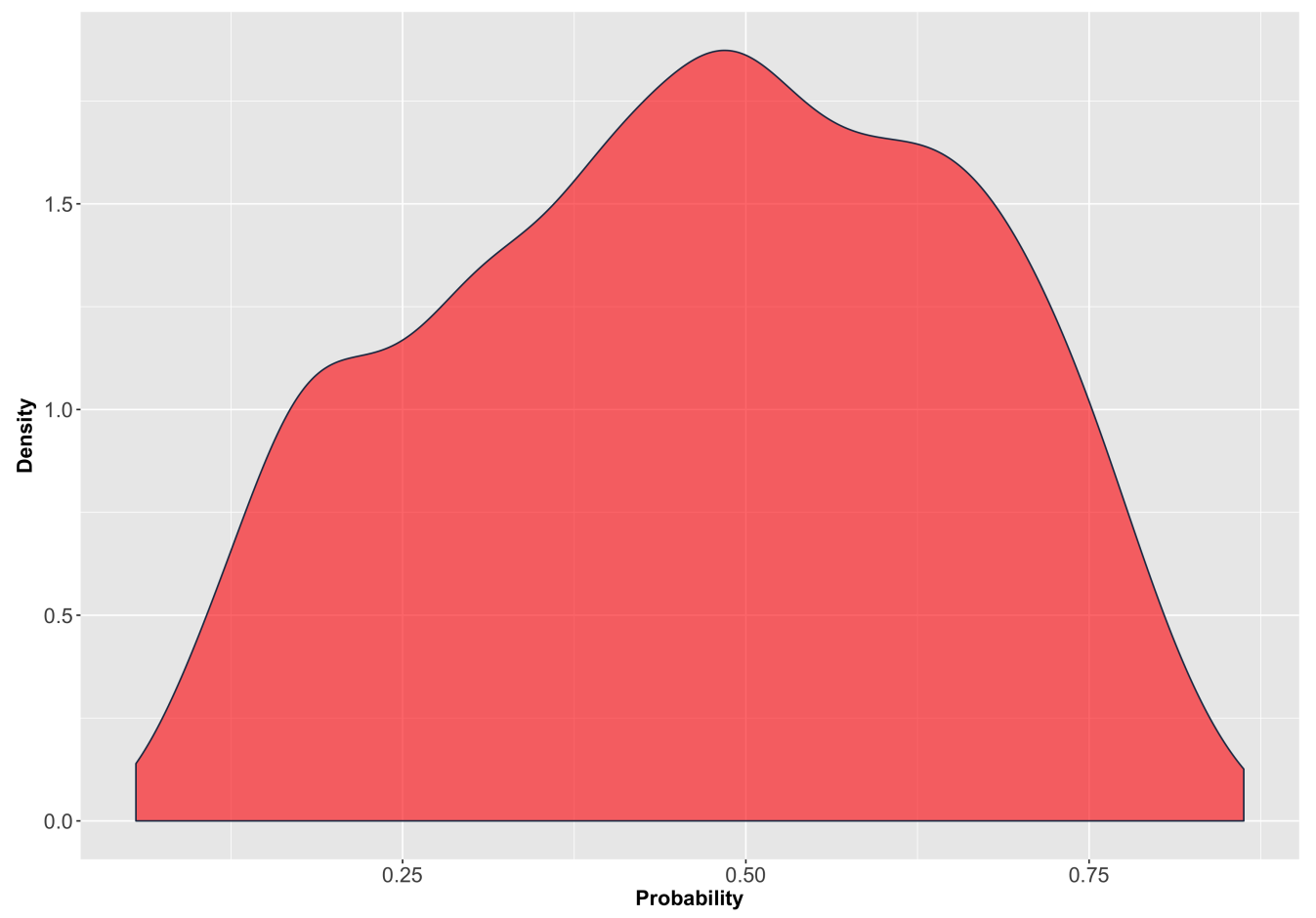

Figure 5: Fractional model: Similar to the work by Arntz et al. (2016) and Nagl et al. (2017), the application of a fractional model (Papke and Wooldridge, 1993) yields a bell-shaped distribution of predicted probabilities. 


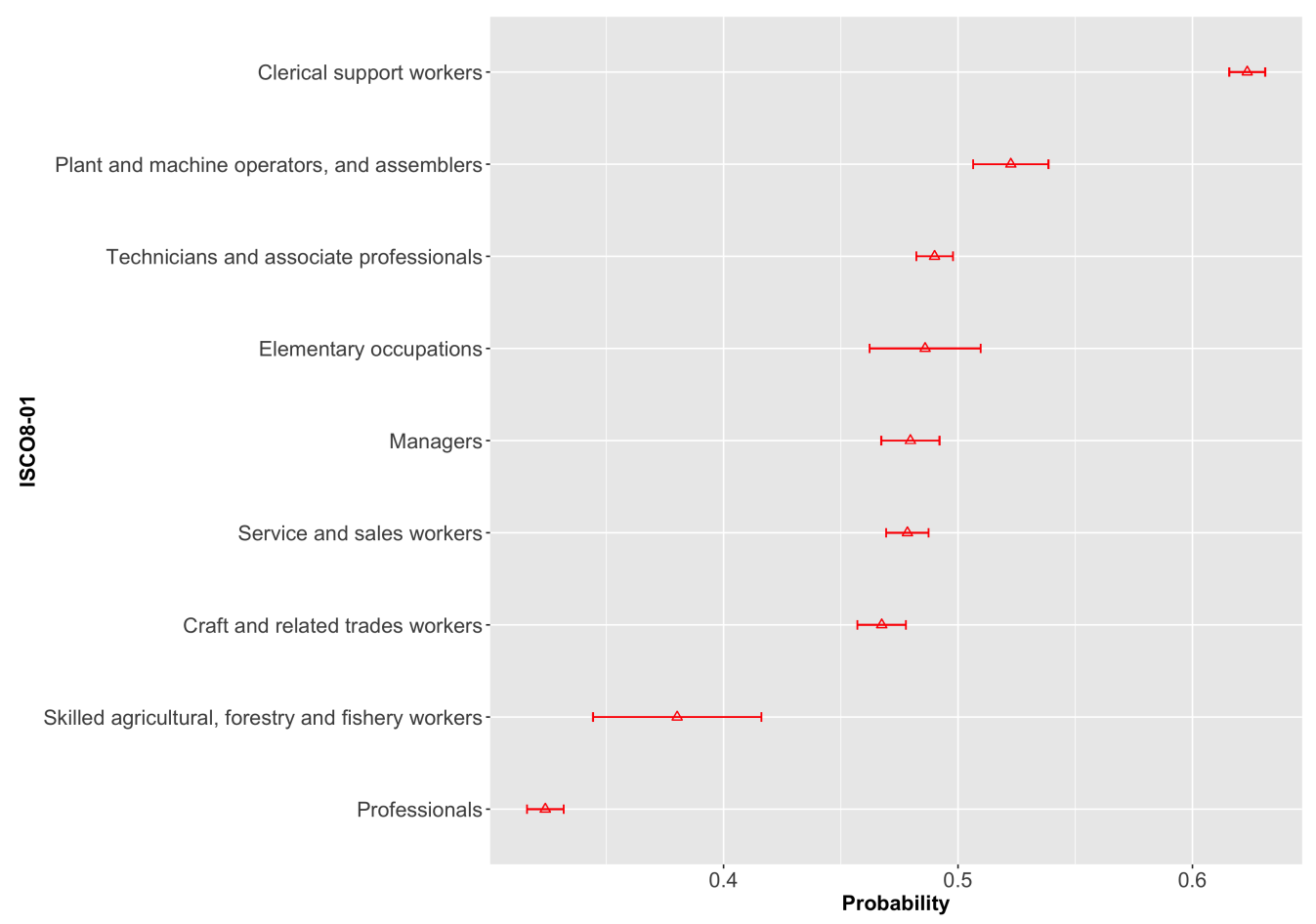

Figure 6: ISCO Level 1: The ranking of occupational classes does not change for the fractional model. However, predicted probabilities converge to the mean. 


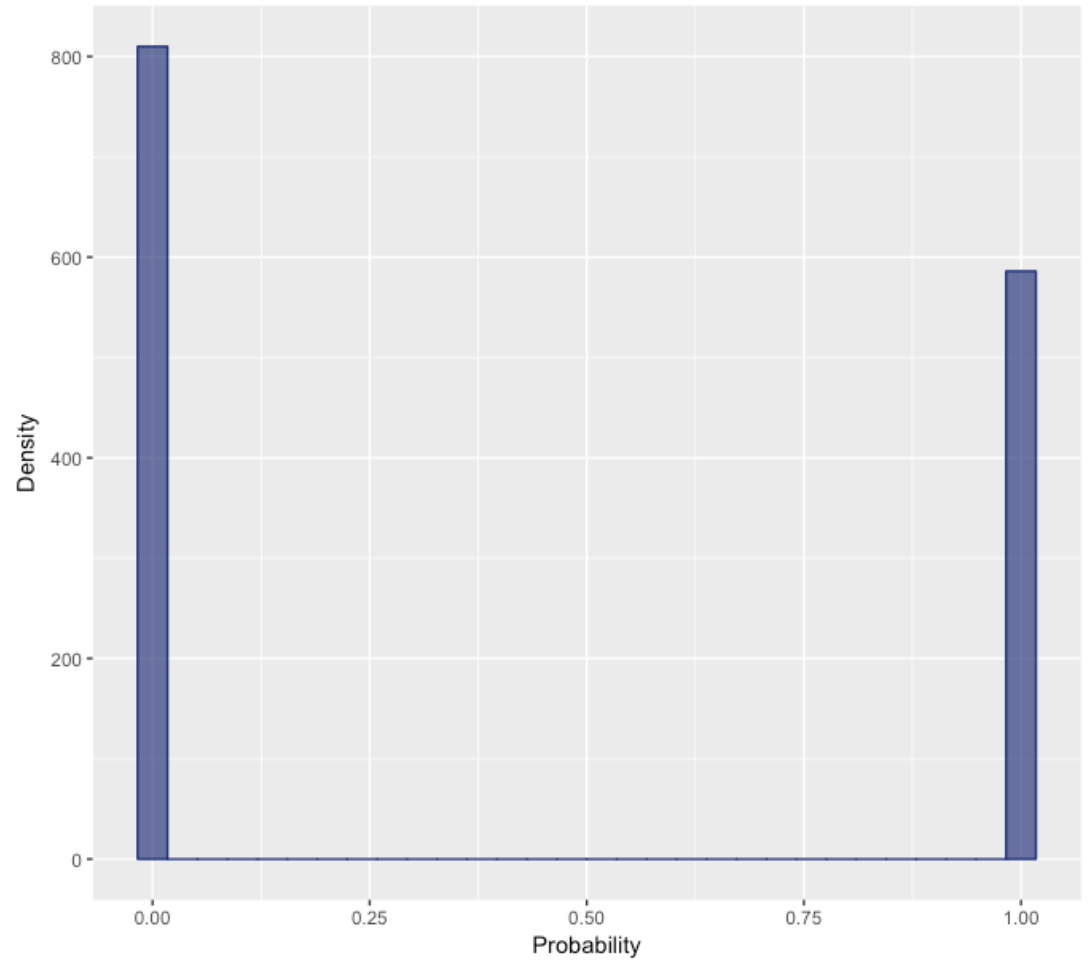

Figure 7: Initial binary distribution: Initially, in the logit model, slightly more individuals are labelled with a consensus outcome of 0 . 


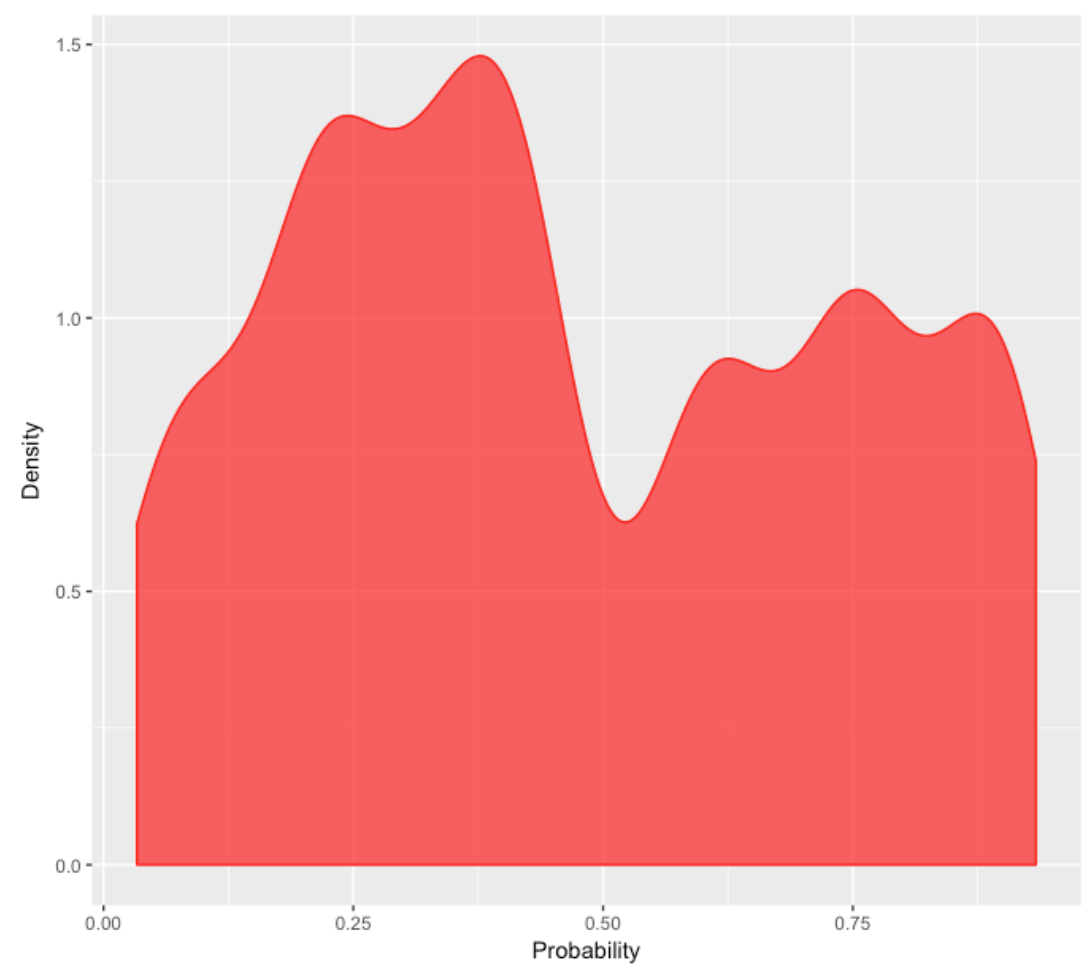

Figure 8: Initial fractional distribution: The initial distribution of the dependent variable in the fractional model is slightly skewed towards the lower values. 
Table 1: Our experts gave their yes/no responses in relation to the 100 most common professions in Austria. The mean, mode and consensus (at least $75 \%$ responded with yes or no) were calculated for each profession.

\begin{tabular}{|c|c|c|c|c|}
\hline ISCO-08-4 Code & ISCO-08-4 Name & Mean & Mode & Consensus \\
\hline 5311 & Childcare workers & 0.033 & 0 & 0 \\
\hline 5120 & Cooks & 0.034 & 0 & 0 \\
\hline 3255 & Physiotherapy technicians and assistants & 0.038 & 0 & 0 \\
\hline 2652 & Musicians, singers and composers & 0.067 & 0 & 0 \\
\hline 5141 & Hairdressers & 0.067 & 0 & 0 \\
\hline 3412 & Social work associate professionals & 0.071 & 0 & 0 \\
\hline 5412 & Police officers & 0.071 & 0 & 0 \\
\hline 2341 & Primary school teachers & 0.074 & 0 & 0 \\
\hline 2635 & Social work and counselling professionals & 0.103 & 0 & 0 \\
\hline 3355 & Police inspectors and detectives & 0.103 & 0 & 0 \\
\hline 5321 & Healthcare assistants & 0.103 & 0 & 0 \\
\hline 6113 & Gardeners, horticultural and nursery growers & 0.111 & 0 & 0 \\
\hline 2161 & Building architects & 0.148 & 0 & 0 \\
\hline 6130 & Mixed crop and animal producers & 0.148 & 0 & 0 \\
\hline 7421 & Electronics mechanics and servicers & 0.160 & 0 & 0 \\
\hline 2212 & Specialist medical practitioners & 0.172 & 0 & 0 \\
\hline 2310 & University and higher education teachers & 0.172 & 0 & 0 \\
\hline 5131 & Waiters & 0.179 & 0 & 0 \\
\hline 7126 & Plumbers and pipe fitters & 0.179 & 0 & 0 \\
\hline 7512 & Bakers, pastry cooks and confectionery makers & 0.185 & 0 & 0 \\
\hline 1349 & Professional services managers not elsewhere classified & 0.192 & 0 & 0 \\
\hline 7412 & Electrical mechanics and fitters & 0.200 & 0 & 0 \\
\hline 1323 & Construction managers & 0.207 & 0 & 0 \\
\hline 1411 & Hotel managers & 0.207 & 0 & 0 \\
\hline 3221 & Nursing associate professionals & 0.222 & 0 & 0 \\
\hline 2330 & Secondary education teachers & 0.231 & 0 & 0 \\
\hline 7411 & Building and related electricians & 0.240 & 0 & 0 \\
\hline 3259 & Health associate professionals not elsewhere classified & 0.250 & 0 & 0 \\
\hline 5151 & Cleaning/housekeeping supervisors in offices, hotels and others & 0.250 & 0 & 0 \\
\hline 2142 & Civil engineers & 0.259 & 0 & . \\
\hline 2149 & Engineering professionals not elsewhere classified & 0.261 & 0 & . \\
\hline 2642 & Journalists & 0.267 & 0 & . \\
\hline 1321 & Manufacturing managers & 0.286 & 0 & . \\
\hline 2611 & Lawyers & 0.296 & 0 & . \\
\hline 2359 & Teaching professionals not elsewhere classified & 0.304 & 0 & . \\
\hline 2144 & Mechanical engineers & 0.308 & 0 & . \\
\hline 3251 & Dental assistants and therapists & 0.321 & 0 & . \\
\hline 3411 & Police inspectors and detectives & 0.321 & 0 & . \\
\hline 3256 & Medical assistants & 0.333 & 0 & . \\
\hline 2166 & Graphic and multimedia designers & 0.345 & 0 & . \\
\hline 2631 & Economists & 0.346 & 0 & . \\
\hline 7233 & Agricultural and industrial machinery mechanics and repairers & 0,346 & 0 & . \\
\hline 7522 & Cabinet makers and related workers & 0.348 & 0 & . \\
\hline 2512 & Software developers & 0.357 & 0 & . \\
\hline 5414 & Security guards & 0.357 & 0 & . \\
\hline 9112 & Cleaners and helpers in offices, hotels and other establishments & 0.357 & 0 & . \\
\hline 7119 & Building frame and related trades workers not elsewhere classified & 0.360 & 0 & . \\
\hline 2421 & Management and organization analysts & 0.370 & 0 & . \\
\hline 5153 & Building caretakers & 0.370 & 0 & . \\
\hline 7112 & Bricklayers and related workers & 0.370 & 0 & . \\
\hline 9412 & Kitchen helpers & 0.385 & 0 & . \\
\hline 3257 & Environmental and occupational health inspectors and associates & 0.400 & 0 & . \\
\hline 7231 & Motor vehicle mechanics and repairers & 0.400 & 0 & . \\
\hline 2431 & Advertising and marketing professionals & 0.407 & 0 & . \\
\hline 7212 & Welders and flame cutters & 0.407 & 0 & . \\
\hline 1324 & Supply, distribution and related managers & 0.414 & 0 & . \\
\hline 3359 & Regulatory government associate professionals & 0.423 & 0 & . \\
\hline 5223 & Shop sales assistants & 0.423 & 0 & . \\
\hline 7543 & Product graders and testers (excluding foods and beverages) & 0.458 & 0 & . \\
\hline 3115 & Mechanical engineering technicians 25 & 0.462 & 0 & . \\
\hline 2262 & Pharmacists & 0.500 & 0 & . \\
\hline
\end{tabular}




\begin{tabular}{|c|c|c|c|c|}
\hline ISCO-08-4 Code & ISCO-08-4 Name & Mean & Mode & Consensus \\
\hline 9629 & Elementary workers not elsewhere classified & 0.500 & 0 & . \\
\hline 7214 & Structural metal preparers and erectors & 0.520 & 1 & . \\
\hline 7523 & Woodworking machine tool setters and operators & 0.520 & 1 & . \\
\hline 8219 & Assemblers not elsewhere classified & 0.538 & 1 & . \\
\hline 3353 & Government social benefits officials & 0.556 & 1 & . \\
\hline 3352 & Government tax and excise officials & 0.571 & 1 & . \\
\hline 8212 & Electrical and electronic equipment assemblers & 0.577 & 1 & . \\
\hline 9332 & Drivers of animal-drawn vehicles and machinery & 0.577 & 1 & . \\
\hline 7223 & Metal working machine tool setters and operators & 0.583 & 1 & . \\
\hline 3322 & Commercial sales representatives & 0.593 & 1 & . \\
\hline 3323 & Buyers & 0.593 & 1 & . \\
\hline 3334 & Real estate agents and property managers & 0.607 & 1 & . \\
\hline 4120 & Secretaries (general) & 0.607 & 1 & . \\
\hline 2411 & Accountants & 0.633 & 1 & . \\
\hline 7321 & Pre-press technicians & 0.640 & 1 & . \\
\hline 9329 & Manufacturing labourers not elsewhere classified & 0.640 & 1 & . \\
\hline 9333 & Freight handlers & 0.652 & 1 & . \\
\hline 8160 & Food and related products machine operators & 0.667 & 1 & . \\
\hline 9334 & Shelf fillers & 0.692 & 1 & . \\
\hline 9621 & Messengers, package deliverers and luggage porters & 0.692 & 1 & . \\
\hline 3118 & Draughtspersons & 0.720 & 1 & . \\
\hline 3313 & Accounting associate professionals & 0.731 & 1 & . \\
\hline 4110 & General office clerks & 0.750 & 1 & 1 \\
\hline 8322 & Car, taxi and van drivers & 0.759 & 1 & 1 \\
\hline 8131 & Chemical products plant and machine operators & 0.792 & 1 & 1 \\
\hline 8332 & Heavy truck and lorry drivers & 0.793 & 1 & 1 \\
\hline 8121 & Metal processing plant operators & 0.800 & 1 & 1 \\
\hline 8122 & Metal finishing, plating and coating machine operators & 0.800 & 1 & 1 \\
\hline 4321 & Stock clerks & 0.828 & 1 & 1 \\
\hline 4412 & Mail carriers and sorting clerks & 0.862 & 1 & 1 \\
\hline 3324 & Trade brokers & 0.867 & 1 & 1 \\
\hline 4322 & Production clerks & 0.875 & 1 & 1 \\
\hline 4312 & Statistical, finance and insurance clerks & 0.897 & 1 & 1 \\
\hline 5230 & Cashiers and ticket clerks & 0.897 & 1 & 1 \\
\hline 3321 & Insurance representatives & 0.900 & 1 & 1 \\
\hline 4222 & Contact centre information clerks & 0.900 & 1 & 1 \\
\hline 4323 & Transport clerks & 0.926 & 1 & 1 \\
\hline 4311 & Accounting and bookkeeping clerks & 0.933 & 1 & 1 \\
\hline
\end{tabular}


Table 2: The PIAAC survey asked employees in Austria and Germany about how frequently they undertake the following 39 tasks at work.

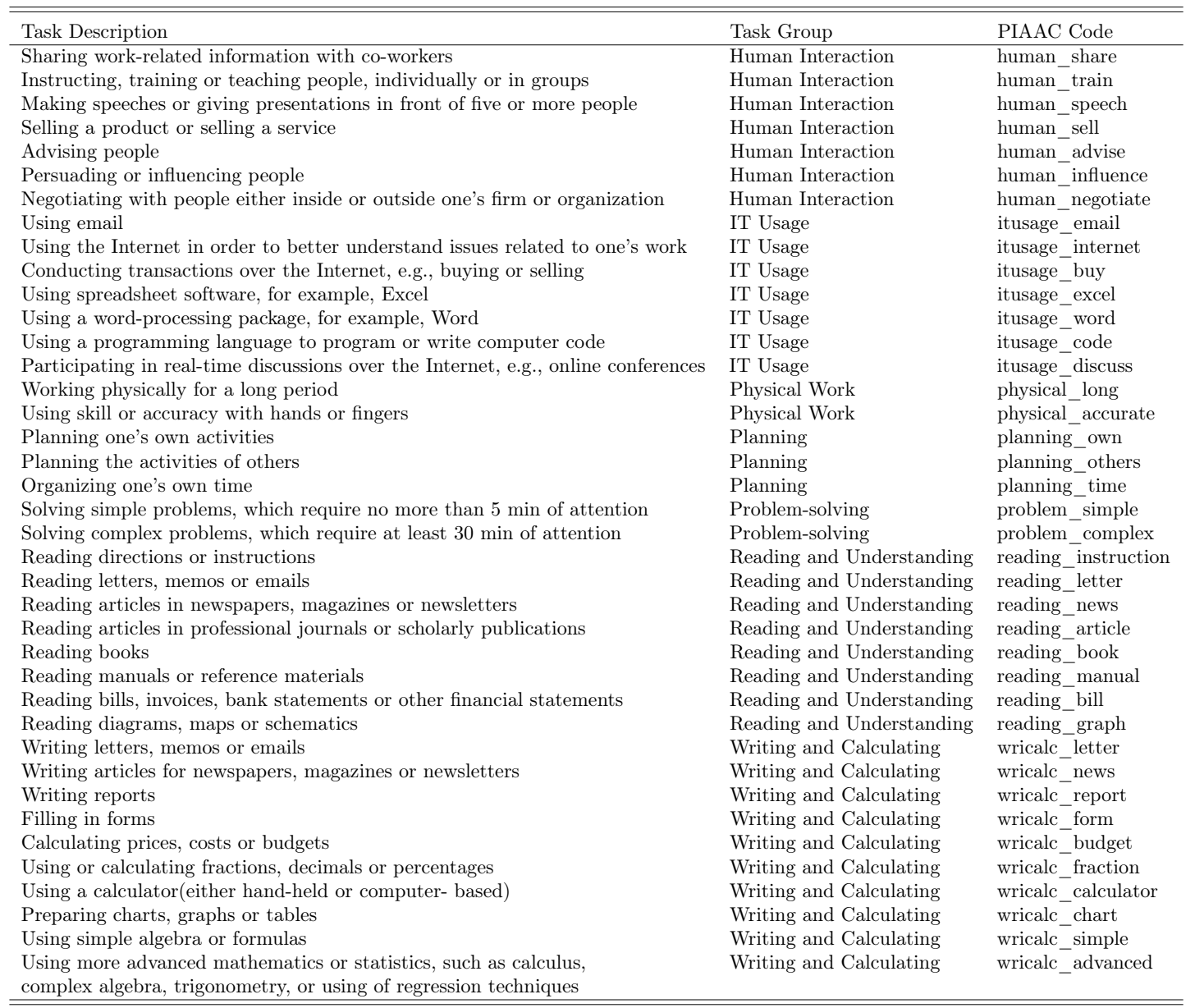


Table 3: Summary of characteristics

\begin{tabular}{|c|c|c|c|c|c|c|}
\hline Name & Observations & & & & & \\
\hline Age Group & & & & & & \\
\hline$"<16-19 "$ & 104 & & & & & \\
\hline "20-24" & 195 & & & & & \\
\hline "25-29" & 255 & & & & & \\
\hline "30-34" & 255 & & & & & \\
\hline "35-39" & 273 & & & & & \\
\hline "40-44" & 309 & & & & & \\
\hline "45-49" & 267 & & & & & \\
\hline "50-54" & 242 & & & & & \\
\hline "55-59" & 119 & & & & & \\
\hline ">60" & 32 & & & & & \\
\hline \multicolumn{7}{|l|}{ Gender } \\
\hline Male & 1,002 & & & & & \\
\hline Female & 1,049 & & & & & \\
\hline \multicolumn{7}{|l|}{ Firm - Sector } \\
\hline "Public or NGO" & 668 & & & & & \\
\hline "Private" & 1,383 & & & & & \\
\hline \multicolumn{7}{|l|}{ Firm - Size } \\
\hline "1-10" & 458 & & & & & \\
\hline "11-50" & 607 & & & & & \\
\hline "51-250" & 480 & & & & & \\
\hline "251-1000" & 326 & & & & & \\
\hline ">1000" & 180 & & & & & \\
\hline \multicolumn{7}{|l|}{ Job - Responsibility } \\
\hline Yes & 1,182 & & & & & \\
\hline No & 869 & & & & & \\
\hline \multicolumn{7}{|l|}{ Job - Experience } \\
\hline "<1 month" & 585 & & & & & \\
\hline "1 to 6 months" & 282 & & & & & \\
\hline "7 to 11 months" & 157 & & & & & \\
\hline "1 or 2 years" & 472 & & & & & \\
\hline "3 years or more" & 555 & & & & & \\
\hline \multicolumn{7}{|l|}{ Job - Education } \\
\hline "<ISCED 3" & 252 & & & & & \\
\hline "ISCED 3-4" & 1,169 & & & & & \\
\hline \multirow[t]{2}{*}{ "ISCED 5+" } & 630 & & & & & \\
\hline & & Min. & $25 \%$ & Mean & $75 \%$ & Max. \\
\hline Education & & & & & & \\
\hline "Years in Full-time Education" & & 4.00 & 13.00 & 14.29 & 16.00 & 20.00 \\
\hline \multicolumn{7}{|l|}{ Skills } \\
\hline Problem-solving & & 168.1 & 268.1 & 290.1 & 313.6 & 404.3 \\
\hline Numeracy & & 160.4 & 269.6 & 294.8 & 321.7 & 409.72 \\
\hline Literacy & & 156.8 & 263.6 & 285.8 & 310.5 & 396.2 \\
\hline
\end{tabular}


Table 4: Models (1)-(6) work with a binary outcome of job digitalisation, while the outcome of model (7) is continuously measured between 0 and 1 . The full binary model (6) with personal/firm/job-level characteristics and tasks shows the best model fit.

\begin{tabular}{|c|c|c|c|c|c|c|c|}
\hline & \multicolumn{7}{|c|}{ Dependent variable } \\
\hline & $\begin{array}{c}\text { Binary } \\
(1)\end{array}$ & $\begin{array}{c}\text { Binary } \\
(2)\end{array}$ & $\begin{array}{c}\text { Binary } \\
(3) \\
\end{array}$ & $\begin{array}{c}\text { Binary } \\
(4)\end{array}$ & $\begin{array}{c}\text { Binary } \\
(5)\end{array}$ & $\begin{array}{c}\text { Binary } \\
(6)\end{array}$ & $\begin{array}{c}\text { Fractional } \\
(7)\end{array}$ \\
\hline \multicolumn{8}{|l|}{ Personal } \\
\hline Age Group & $\begin{array}{l}0.069^{*} \\
(0.040)\end{array}$ & $\begin{array}{c}0.106^{* *} \\
(0.046)\end{array}$ & $\begin{array}{c}0.175^{* * *} \\
(0.057)\end{array}$ & $\begin{array}{c}0.105 \\
(0.068)\end{array}$ & & $\begin{array}{c}0.141 \\
(0.094)\end{array}$ & $\begin{array}{c}0.025 \\
(0.037)\end{array}$ \\
\hline Gender & -0.021 & $0.466^{* *}$ & $0.565^{* *}$ & 0.130 & & 0.183 & 0.051 \\
\hline (Ref. male) & $(0.192)$ & $(0.225)$ & $(0.253)$ & $(0.337)$ & & $(0.419)$ & $(0.166)$ \\
\hline Education & $0.952^{* * *}$ & $0.723^{* *}$ & $1.005^{* * *}$ & $1.411^{* * *}$ & & $1.489^{* * *}$ & 0.133 \\
\hline (Years) & $(0.283)$ & $(0.305)$ & $(0.355)$ & $(0.419)$ & & $(0.495)$ & $(0.230)$ \\
\hline Education $^{2}$ & $\begin{array}{c}-0.050^{* * *} \\
(0.011)\end{array}$ & $\begin{array}{c}-0.038^{* * *} \\
(0.012)\end{array}$ & $\begin{array}{c}-0.049^{* * *} \\
(0.014)\end{array}$ & $\begin{array}{c}-0.071^{* * *} \\
(0.017)\end{array}$ & & $\begin{array}{c}-0.070^{* * *} \\
(0.020)\end{array}$ & $\begin{array}{l}-0.008 \\
(0.008)\end{array}$ \\
\hline \multicolumn{8}{|l|}{ Firm } \\
\hline $\begin{array}{l}\text { Firm - Sector } \\
\text { (Ref. public) }\end{array}$ & & $\begin{array}{c}2.300^{* * * *} \\
(0.240)\end{array}$ & $\begin{array}{c}2.170^{* * *} \\
(0.263)\end{array}$ & & & $\begin{array}{c}1.695^{* * *} \\
(0.454)\end{array}$ & $\begin{array}{c}0.522^{* * * *} \\
(0.188)\end{array}$ \\
\hline Firm - Size & & 0.085 & 0.129 & & & $0.408^{* *}$ & $0.104^{*}$ \\
\hline$(0-4)$ & & $(0.090)$ & $(0.100)$ & & & $(0.168)$ & $(0.061)$ \\
\hline \multicolumn{8}{|l|}{ Job } \\
\hline Job - Responsibility & & & -0.200 & & & $-0.979^{* *}$ & -0.039 \\
\hline (Ref. no responsibility) & & & $(0.264)$ & & & $(0.486)$ & $(0.178)$ \\
\hline Job - Experience & & & $0.151^{*}$ & & & -0.006 & -0.006 \\
\hline$(0-4)$ & & & $(0.087)$ & & & $(0.151)$ & $(0.055)$ \\
\hline Job - Education & & & $-1.293^{* * *}$ & & & $-1.919^{* * *}$ & $-0.483^{* * *}$ \\
\hline$(0-2)$ & & & $(0.230)$ & & & $(0.424)$ & $(0.148)$ \\
\hline Skill - Problem-solving & & & -0.0003 & & & $-0.018^{*}$ & -0.001 \\
\hline (Test Score) & & & $(0.006)$ & & & $(0.010)$ & $(0.004)$ \\
\hline Skill - Numeracy & & & $0.021^{* * *}$ & & & 0.008 & 0.003 \\
\hline (Test score) & & & $(0.007)$ & & & $(0.011)$ & $(0.005)$ \\
\hline Skill - Literacy & & & -0.006 & & & 0.009 & -0.003 \\
\hline (Test score) & & & $(0.008)$ & & & $(0.013)$ & $(0.005)$ \\
\hline Cooperate with Humans & & & -0.360 & & & -0.307 & -0.167 \\
\hline (Frequency) & & & $(0.342)$ & & & $(0.589)$ & $(0.225)$ \\
\hline \multicolumn{8}{|l|}{ Tasks } \\
\hline \multirow[t]{2}{*}{ human_share } & & & & 0.769 & 0.730 & 0.880 & 0.083 \\
\hline & & & & $(0.507)$ & $(0.480)$ & $(0.619)$ & $(0.254)$ \\
\hline \multirow[t]{2}{*}{ human_train } & & & & -0.263 & -0.483 & 0.183 & -0.090 \\
\hline & & & & $(0.550)$ & $(0.522)$ & $(0.688)$ & $(0.249)$ \\
\hline \multirow[t]{2}{*}{ human_speech } & & & & $-2.445^{* *}$ & $-3.299^{* * *}$ & $-2.562^{* *}$ & -0.257 \\
\hline & & & & $(1.020)$ & $(0.966)$ & $(1.188)$ & $(0.357)$ \\
\hline \multirow[t]{2}{*}{ human_sell } & & & & $0.765^{*}$ & $0.847^{* *}$ & $0.966^{*}$ & 0.117 \\
\hline & & & & $(0.455)$ & $(0.411)$ & $(0.550)$ & $(0.214)$ \\
\hline \multirow[t]{2}{*}{ human_advise } & & & & -0.507 & -0.560 & -0.622 & -0.109 \\
\hline & & & & $(0.443)$ & $(0.419)$ & $(0.519)$ & $(0.216)$ \\
\hline \multirow[t]{2}{*}{ human_influence } & & & & $-1.236^{* * *}$ & $-1.081^{* *}$ & -0.886 & -0.249 \\
\hline & & & & $(0.474)$ & $(0.429)$ & $(0.559)$ & $(0.212)$ \\
\hline \multirow[t]{2}{*}{ human_negotiate } & & & & 0.478 & 0.369 & 0.891 & 0.115 \\
\hline & & & & $(0.555)$ & $(0.494)$ & $(0.660)$ & $(0.236)$ \\
\hline \multirow[t]{2}{*}{ itusage_email } & & & & 0.870 & 0.808 & 1.134 & 0.255 \\
\hline & & & & $(0.621)$ & $(0.572)$ & $(0.763)$ & $(0.284)$ \\
\hline \multirow[t]{2}{*}{ itusage_internet } & & & & 0.688 & 0.422 & 0.727 & 0.044 \\
\hline & & & & $(0.515)$ & $(0.468)$ & $(0.600)$ & $(0.229)$ \\
\hline \multirow[t]{2}{*}{ itusage_buy } & & & & 0.573 & $1.428^{* *}$ & 0.052 & 0.198 \\
\hline & & & & $(0.632)$ & $(0.624)$ & $(0.711)$ & $(0.270)$ \\
\hline itusage_excel & & & & 0.612 & $0.717^{*}$ & $1.080^{*}$ & 0.224 \\
\hline & & & & $(0.471)$ & $(0.430)$ & $(0.565)$ & $(0.226)$ \\
\hline itusage_word & & & 29 & $-0.886^{*}$ & -0.714 & $-1.117^{*}$ & 0.028 \\
\hline & & & & $(0.517)$ & $(0.479)$ & $(0.641)$ & $(0.228)$ \\
\hline itusage_code & & & & $-1.780^{* *}$ & $-1.282^{*}$ & $-2.234^{* *}$ & -0.251 \\
\hline & & & & $(0.795)$ & $(0.771)$ & $(0.910)$ & $(0.423)$ \\
\hline itusage_discuss & & & & $\begin{array}{c}2.559 \\
(1.604)\end{array}$ & $\begin{array}{l}2.909^{*} \\
(1.654)\end{array}$ & $\begin{array}{l}3.612^{*} \\
(1.939)\end{array}$ & $\begin{array}{l}-0.163 \\
(0.505)\end{array}$ \\
\hline
\end{tabular}




\begin{tabular}{|c|c|c|c|c|c|c|c|}
\hline & \multicolumn{7}{|c|}{ Dependent variable } \\
\hline & $\begin{array}{c}\text { Binary } \\
(1)\end{array}$ & $\begin{array}{c}\text { Binary } \\
(2)\end{array}$ & $\begin{array}{c}\text { Binary } \\
(3)\end{array}$ & $\begin{array}{c}\text { Binary } \\
(4) \\
\end{array}$ & $\begin{array}{c}\text { Binary } \\
(5)\end{array}$ & $\begin{array}{c}\text { Binary } \\
(6)\end{array}$ & $\begin{array}{c}\text { Fractional } \\
(7)\end{array}$ \\
\hline physical_long & & & & $\begin{array}{c}-1.906^{* * *} \\
(0.435)\end{array}$ & $\begin{array}{c}-1.561^{* * *} \\
(0.406)\end{array}$ & $\begin{array}{c}-2.439^{* * *} \\
(0.529)\end{array}$ & $\begin{array}{c}-0.536^{* *} \\
(0.212)\end{array}$ \\
\hline physical_accurate & & & & $\begin{array}{c}-0.014 \\
(0.387)\end{array}$ & $\begin{array}{c}0.138 \\
(0.356)\end{array}$ & $\begin{array}{c}0.183 \\
(0.471)\end{array}$ & $\begin{array}{l}-0.059 \\
(0.174)\end{array}$ \\
\hline planning_own & & & & $\begin{array}{l}-0.364 \\
(0.424)\end{array}$ & $\begin{array}{l}-0.580 \\
(0.394)\end{array}$ & $\begin{array}{l}-0.463 \\
(0.504)\end{array}$ & $\begin{array}{c}-0.196 \\
(0.186)\end{array}$ \\
\hline planning_others & & & & $\begin{array}{l}-0.431 \\
(0.576)\end{array}$ & $\begin{array}{l}-0.459 \\
(0.520)\end{array}$ & $\begin{array}{c}0.193 \\
(0.692)\end{array}$ & $\begin{array}{c}0.014 \\
(0.271)\end{array}$ \\
\hline planning_time & & & & $\begin{array}{c}-0.841^{*} \\
(0.459)\end{array}$ & $\begin{array}{c}-0.945^{* *} \\
(0.425)\end{array}$ & $\begin{array}{l}-0.454 \\
(0.532)\end{array}$ & $\begin{array}{l}-0.003 \\
(0.216)\end{array}$ \\
\hline problem_simple & & & & $\begin{array}{c}0.246 \\
(0.439)\end{array}$ & $\begin{array}{c}0.336 \\
(0.412)\end{array}$ & $\begin{array}{c}0.056 \\
(0.509)\end{array}$ & $\begin{array}{l}-0.004 \\
(0.202)\end{array}$ \\
\hline problem_complex & & & & $\begin{array}{l}-0.217 \\
(0.557)\end{array}$ & $\begin{array}{l}-0.255 \\
(0.534)\end{array}$ & $\begin{array}{c}0.050 \\
(0.652)\end{array}$ & $\begin{array}{l}-0.075 \\
(0.266)\end{array}$ \\
\hline reading_instruction & & & & $\begin{array}{l}0.865^{*} \\
(0.465)\end{array}$ & $\begin{array}{l}0.946^{* *} \\
(0.422)\end{array}$ & $\begin{array}{c}0.801 \\
(0.520)\end{array}$ & $\begin{array}{c}0.085 \\
(0.201)\end{array}$ \\
\hline reading_letter & & & & $\begin{array}{c}0.792 \\
(0.723)\end{array}$ & $\begin{array}{c}0.399 \\
(0.666)\end{array}$ & $\begin{array}{c}0.165 \\
(0.849)\end{array}$ & $\begin{array}{c}0.234 \\
(0.334)\end{array}$ \\
\hline reading_news & & & & $\begin{array}{l}-0.443 \\
(0.520)\end{array}$ & $\begin{array}{l}-0.155 \\
(0.471)\end{array}$ & $\begin{array}{c}0.310 \\
(0.659)\end{array}$ & $\begin{array}{l}-0.011 \\
(0.229)\end{array}$ \\
\hline reading_article & & & & $\begin{array}{l}-0.665 \\
(0.781)\end{array}$ & $\begin{array}{l}-0.720 \\
(0.718)\end{array}$ & $\begin{array}{l}-0.969 \\
(0.940)\end{array}$ & $\begin{array}{l}-0.047 \\
(0.322)\end{array}$ \\
\hline reading_book & & & & $\begin{array}{c}-3.639^{* * *} \\
(1.064)\end{array}$ & $\begin{array}{c}-3.855^{* * *} \\
(1.086)\end{array}$ & $\begin{array}{c}-3.632^{* * *} \\
(1.249)\end{array}$ & $\begin{array}{l}-0.304 \\
(0.352)\end{array}$ \\
\hline reading_manual & & & & $\begin{array}{l}-0.303 \\
(0.594)\end{array}$ & $\begin{array}{l}-0.341 \\
(0.566)\end{array}$ & $\begin{array}{l}-0.306 \\
(0.692)\end{array}$ & $\begin{array}{c}0.090 \\
(0.258)\end{array}$ \\
\hline reading_bill & & & & $\begin{array}{c}0.697 \\
(0.500)\end{array}$ & $\begin{array}{c}0.689 \\
(0.453)\end{array}$ & $\begin{array}{l}1.227^{* * *} \\
(0.600)\end{array}$ & $\begin{array}{c}0.212 \\
(0.212)\end{array}$ \\
\hline reading_graph & & & & $\begin{array}{c}0.156 \\
(0.462)\end{array}$ & $\begin{array}{c}0.236 \\
(0.428)\end{array}$ & $\begin{array}{c}0.192 \\
(0.546)\end{array}$ & $\begin{array}{l}-0.009 \\
(0.201)\end{array}$ \\
\hline wricalc_letter & & & & $\begin{array}{l}-0.644 \\
(0.661)\end{array}$ & $\begin{array}{l}-0.614 \\
(0.638)\end{array}$ & $\begin{array}{l}-0.112 \\
(0.762)\end{array}$ & $\begin{array}{l}-0.218 \\
(0.304)\end{array}$ \\
\hline wricalc_news & & & & $\begin{array}{c}2.055 \\
(3.602)\end{array}$ & $\begin{array}{c}3.158 \\
(2.784)\end{array}$ & $\begin{array}{c}4.665 \\
(4.245)\end{array}$ & $\begin{array}{c}0.148 \\
(1.017)\end{array}$ \\
\hline wricalc_report & & & & $\begin{array}{c}-2.091^{* * *} \\
(0.446)\end{array}$ & $\begin{array}{c}-1.980^{* * *} \\
(0.422)\end{array}$ & $\begin{array}{c}-1.676^{* * *} \\
(0.534)\end{array}$ & $\begin{array}{c}-0.415^{* *} \\
(0.207)\end{array}$ \\
\hline wricalc_form & & & & $\begin{array}{c}-0.169 \\
(0.401)\end{array}$ & $\begin{array}{c}-0.135 \\
(0.380)\end{array}$ & $\begin{array}{l}-0.225 \\
(0.464)\end{array}$ & $\begin{array}{c}0.138 \\
(0.185)\end{array}$ \\
\hline wricalc_budget & & & & $\begin{array}{c}0.006 \\
(0.511)\end{array}$ & $\begin{array}{c}0.016 \\
(0.467)\end{array}$ & $\begin{array}{l}-0.473 \\
(0.604)\end{array}$ & $\begin{array}{l}-0.034 \\
(0.228)\end{array}$ \\
\hline wricalc_fraction & & & & $\begin{array}{c}0.861^{*} \\
(0.513)\end{array}$ & $\begin{array}{c}0.745 \\
(0.496)\end{array}$ & $\begin{array}{c}0.827 \\
(0.599)\end{array}$ & $\begin{array}{c}0.062 \\
(0.232)\end{array}$ \\
\hline wricalc_calculator & & & & $\begin{array}{c}2.111^{* * *} \\
(0.441)\end{array}$ & $\begin{array}{c}2.097^{* * *} \\
(0.413)\end{array}$ & $\begin{array}{c}1.893^{* * *} \\
(0.531)\end{array}$ & $\begin{array}{l}0.478^{* *} \\
(0.224)\end{array}$ \\
\hline wricalc_chart & & & & $\begin{array}{c}0.363 \\
(0.695)\end{array}$ & $\begin{array}{l}-0.060 \\
(0.648)\end{array}$ & $\begin{array}{c}0.740 \\
(0.809)\end{array}$ & $\begin{array}{l}-0.079 \\
(0.287)\end{array}$ \\
\hline wricalc_simple & & & & $\begin{array}{l}-0.408 \\
(0.533)\end{array}$ & $\begin{array}{l}-0.578 \\
(0.517)\end{array}$ & $\begin{array}{l}-0.535 \\
(0.640)\end{array}$ & $\begin{array}{c}0.032 \\
(0.237)\end{array}$ \\
\hline wricalc_advanced & & & & $\begin{array}{c}2.041 \\
(1.247)\end{array}$ & $\begin{array}{c}0.800 \\
(1.103)\end{array}$ & $\begin{array}{c}2.647 \\
(1.923)\end{array}$ & $\begin{array}{l}-0.006 \\
(0.492)\end{array}$ \\
\hline Constant & $\begin{array}{c}-3.708^{*} \\
(1.895) \\
\end{array}$ & $\begin{array}{c}-7.828^{* * *} \\
(2.088)\end{array}$ & $\begin{array}{c}-11.294^{* * *} \\
(2.726)\end{array}$ & $\begin{array}{c}-6.391^{* *} \\
(2.783) \\
\end{array}$ & $\begin{array}{c}0.154 \\
(0.551) \\
\end{array}$ & $\begin{array}{c}-6.814^{*} \\
(4.092) \\
\end{array}$ & $\begin{array}{l}-0.768 \\
(1.805) \\
\end{array}$ \\
\hline $\begin{array}{l}\text { Observations } \\
\text { Akaike Inf. Crit. }\end{array}$ & $\begin{array}{c}541 \\
663.473\end{array}$ & $\begin{array}{c}541 \\
558.371\end{array}$ & $\begin{array}{c}541 \\
506.827\end{array}$ & $\begin{array}{c}541 \\
391.567\end{array}$ & $\begin{array}{c}541 \\
421.820\end{array}$ & $\begin{array}{c}541 \\
347.170\end{array}$ & $\begin{array}{c}995 \\
1,122.227\end{array}$ \\
\hline
\end{tabular}

Note:

${ }^{*} \mathrm{p}<0.1 ;{ }^{* *} \mathrm{p}<0.05 ;{ }^{* * *} \mathrm{p}<0.01 ;$ Standard errors are shown in parentheses 
Table 5: When comparing the outcome reported in past contributions with our findings, the choice of model clearly dictates the resulting probabilities. Models with a binary dependent variable lead to bimodal distributions with large high-risk groups. Fractional models yield a normal distribution with small high-risk shares.

\begin{tabular}{|c|c|c|c|c|c|}
\hline Author & Initial Input & Model Type & $\begin{array}{l}\text { Predicted } \\
\text { Distribution }\end{array}$ & High Risk & Country \\
\hline Frey and Osborne 2017 & Binary $(0 / 1)$ & Classification & Bimodal & $47 \%$ & US \\
\hline Bowles (2014) & transfer of Frey & and Osborne (2017) & Bimodal & $54 \%$ & $\mathrm{AT}$ \\
\hline Arntz et al. (2016) & Discrete $(0-1)$ & Fractional & Normal & $12 \%$ & $\mathrm{AT}$ \\
\hline Nagl et al. 2017) & Discrete $(0-1)$ & Fractional & Normal & $9 \%$ & $\mathrm{AT}$ \\
\hline Own calculations & Binary $(0 / 1)$ & Logit & Bimodal & $45 \%$ & $\mathrm{AT}$ \\
\hline Own calculations & Discrete $(0-1)$ & Fractional & Normal & $12 \%$ & $\mathrm{AT}$ \\
\hline Own calculations & Binary $(0 / 1)$ & LDA & Bimodal & $46 \%$ & $\mathrm{AT}$ \\
\hline
\end{tabular}




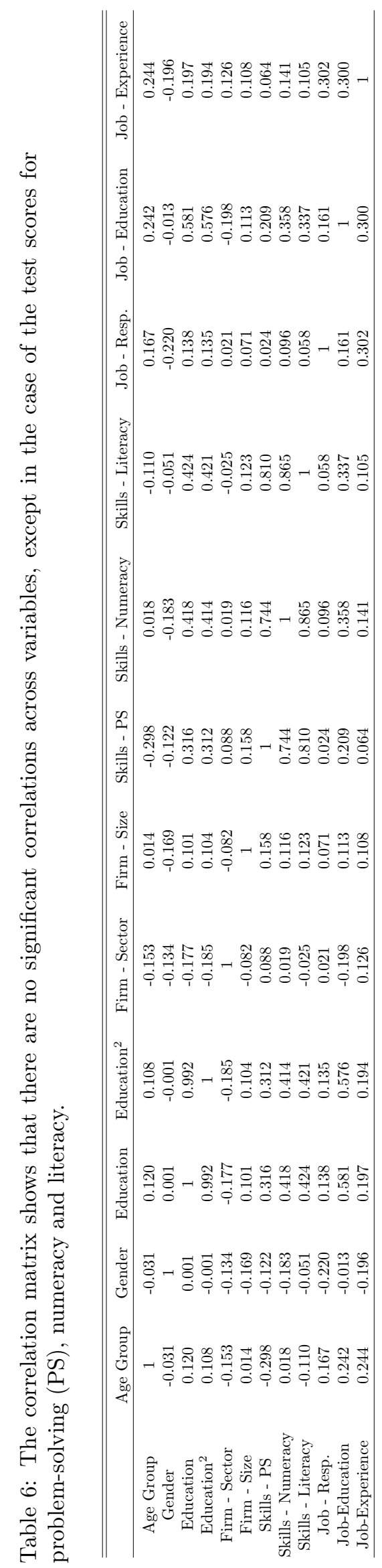

